Journal of Telenursing (JOTING)

Volume 2, Nomor 1, Juni 2020

e-ISSN: 2684-8988

p-ISSN: 2684-8996

DOI: https://doi.org/10.31539/joting.v2i1.1098

\title{
TERAPI MUSIK BABY SHARK MAMPU MENURUNKAN KECEMASAN PADA ANAK USIA PRASEKOLAH
}

\author{
Elfira Awalia Rahmawati \\ Akademi Keperawatan Pelni Jakarta \\ elfira.wijaya@gmail.com
}

\begin{abstract}
ABSTRAK
Penelitian ini bertujuan untuk mengetahui pengaruh terapi musik baby shark terhadap kecemasan anak usia prasekolah di Rumah Sakit Pelni Jakarta. Metode penelitian ini merupakan metode deskriptif sederhana dengan desain penelitian adalah studi kasus. Hasil penelitian studi kasus dengan terapi musik baby shark memberikan pengaruh yang dapat mengurangi tingkat kecemasan pada anak saat berada di Rumah Sakit. Terjadi penurunan kecemasan pada kedua subjek penelitian yaitu dari kecemasan sedang pada awal pengkajian menjadi kecemasan ringan dan tidak ada kecemasan pada hari ketiga penelitian. Simpulan, terapi musik baby shark dapat menurunkan tingkat kecemasan pada anak usia prasekolah.
\end{abstract}

Kata Kunci: Baby Shark, Hospitalisasi, Kecemasan, Prasekolah, Terapi Musik

\section{ABSTRACT}

This study aims to determine the effect of baby shark music therapy on preschoolers' anxiety at Pelni Hospital in Jakarta. This research method is a simple descriptive method with a research design that is a case study. The results of case study research with baby shark music therapy have an effect that can reduce the level of anxiety in children while in the hospital. There was a decrease in anxiety in both study subjects, from moderate anxiety at the beginning of the assessment to mild stress and no strain on the third day of the study. In conclusion, baby shark music therapy can reduce anxiety levels in preschool children.

Keywords: Baby Shark, Hospitalization, Anxiety, Preschool, Music Therapy

\section{PENDAHULUAN}

Angka kesakitan anak di Indonesia berdasarkan Survei Kesehatan Nasional (Susenas) tahun 2010 didaerah perkotaan menurut kelompok usia 0-4 tahun sebesar $25,8 \%$, usia 5-12 tahun sebanyak 14,91\%, usia 13-15 tahun sekitar 9,1\%, usia 16-21 tahun sebesar 8,13\%. Angka kesakitan anak usia 0-21 tahun apabila dihitung dari keseluruhan jumlah penduduk adalah 14,44\%. Angka kesakitan anak di Indonesia yang dirawat di rumah sakit cukup tinggi yaitu sekitar 35 dari 100 anak yang di tunjukkan dengan selalu penuhnya ruangan anak baik rumah sakit pemerintah maupun rumah sakit swasta (Sari \& Suryani, 2017).

Masa anak dianggap sebagai fase yang penting karena akan menentukan kualitas kesehatan, kesejahteraan, pembelajaran, dan perilaku dimasa yang akan datang serta masa depan masyarakat tergantung pada anak yang mampu mencapai pertumbuhan dan 
perkembangan yang optimal. Pertumbuhan pada masa anak mengalami perbedaan yang bervariasi sesuai dengan bertambahnya usia anak (Padila et al., 2019; Padila et al, 2019; WHO, 2017).

Hospitalisasi merupakan kondisi krisis bagi anak. Kondisi krisis ini terjadi karena anak mencoba beradaptasi dengan lingkungan yang dianggapnya asing dan baru, sehingga kondisi tersebut mengharuskan anak untuk berpisah dengan lingkungan yang dirasakannya aman (Oktiawati, 2017; Legi et al., 2019)

Menurut World Health Organization (WHO), pada tahun 2008 hampir 80\% anak mengalami perawatan di rumah sakit. The National Centre for Health Statistic memperkirakan bahwa 3-5 juta anak dibawah usia 15 tahun menjalani hospitalisasi setiap tahun. Angka kesakitan anak di Indonesia yang dirawat di rumah sakit cukup tinggi yaitu 15,26\% yang ditunjukkan dengan selalu penuhnya ruangan anak baik rumah sakit pemerintah maupun swasta. Angka kesakitan anak di Indonesia berdasarkan Survei Kesehatan Nasional (Susenas) tahun 2010 di daerah perkotaan sebesar 25,8\% menurut kelompok usia 0-4 tahun, sebanyak 14,91\% usia 5-12 tahun, usia 13-15 tahun sekitar 9,1\%, usia 16-21 tahun sebesar 8,13\%. Angka kesakitan anak usia 0-21 tahun apabila dihitung dari jumlah keseluruhan jumlah penduduk adalah 14,44\% (Badan Penelitian dan Pengembangan Kesehatan, 2013).

Penelitian yang dilakukan Kazemi et al., (2012) menyatakan bahwa musik secara signifikan dapat mengurangi kecemasan pada anak usia sekolah yang mengalami hospitalisasi. Selain itu, dalam studinya dikatakan juga bahwa efek negatif dari kecemasan akibat hospitalisasi dapat dikurangi dengan terapi musik di rumah sakit (Ariani et al., 2015).

Selama anak menjalani proses hospitalisasi, perawat diharapkan mampu melakukan tindakan mengurangi respon stress terhadap hospitalisasi seperti meminimalkan pengaruh perpisahan, meminimalkan kehilangan kontrol pada anak, memaksimalkan manfaat hospitalisasi anak, mendukung anggota keluarga dan mempersiapkan anak untuk hospitalisasi (Hockenberry \& Wilson, 2013). Distraksi melalui audio, visual, dan audio visual adalah salah satu bentuk pengalihan perhatian yang efektif untuk anak usia prasekolah yang sedang dalam proses hospitalisasi (Padila et al., 2019).

Audiovisual yang dapat kita berikan tentunya yang sesuai dengan usia anak, seperti kartun animasi baby shark, anak usia prasekolah sangat mudah dialihkan, salah satunya dengan menonton animasi kartun sehingga teknik distraksi dapat membantu dalam manajemen nyeri dan cemas (Sarfika, 2015). Berdasarkan latar belakang diatas dan dari pengamatan yang peneliti dapatkan serta fenomena yang terjadi selama praktik di Ruang Cempaka Anak Rumah Sakit Pelni hampir seluruh anak yang dirawat mengalami dampak hospitalisasi dan kecemasan, contohnya pada saat perawat akan melakukan tindakan keperawatan seperti pemasangan infus anak yang dirawat langsung ketakutan, menangis, bahkan sampai berteriak dan berontak saat akan dilakukan pemasangan infus. Hampir setiap anak yang mengalami hospitalisasi dan kecemasan tidak diberikan terapi oleh perawat ruangan baik terapi bermain ataupun terapi lainnya.

\section{METODE PENELITIAN}

Jenis Penelitian ini merupakan penelitian kuantitatif yang dipilih untuk penelitian yang akan dilaksanakan yaitu studi kasus. Penelitian ini melibatkan 2 individu yaitu anak yang dilakukan intervensi pemberian terapi musik baby shark untuk menurunkan tingkat kecemasan akibat hospitalisasi pada anak. Instrumen yang digunakan yaitu 
lembar kuisioner kecemasan Spance Children Anxiety Scale (SCAC), lembar observasi, handphone dan video musik baby shark.

Kriteria inklusi pada sampel penelitian ini adalah anak usia prasekolah (3-6 tahun) anak yang mengalami dampak hospitalisasi kecemasan, anak yang baru menjalani perawatan di rumahsakit, lama perawatan anak minimal 3 hari masa perawatan, dan orang tua bersedia apabila anak menjadi subjek penelitian.

Kriteria eksklusi pada sampel penelitian ini adalah usia anak yang tidak sesuai dengan kriteria yang akan dilakukan penelitian, anak yang dirawat dengan lama perawatan lebih dari 3 hari masa perawatan, orang tua menolak apabila anak akan dijadikan subjek penelitian, anak yangtidak mengalami kecemasan akibat dampak dari hospitalisasi, anak yang mengalami penurunan kesadaran dan anak yang memiliki gangguan mental.

\section{HASIL PENELITIAN}

Tabel. 1

Proses Intervensi Subjek Penelitian I

\begin{tabular}{llrll}
\hline \multicolumn{2}{c}{ Pertemuan } & \multicolumn{2}{c}{ Tujuan } & \multicolumn{2}{c}{ Respon } & Kemajuan \\
\hline Pertemuan I & Pengkajian, & Bina & An.M tampak takut kepada & An. M tertarik terhadap \\
18 Juli 2019 & Hubungan & Saling & perawat, wajah tampak tegang ajakan perawat untuk \\
Pukul 15.00 & Percaya & dan & dan cemberut, mata tajam menonton video musik \\
WIB & penurunan & tingkat & menatap perawat, skor baby shark yang akan \\
& kecemasan & & $\begin{array}{l}\text { kecemasan sebelum dilakukan diberikan besok oleh } \\
\text { tindakan terapi musik baby perawat }\end{array}$
\end{tabular}

shark yaitu 55 merupakan

kecemasan sedang. An.M

belum dapat mengikuti arahan dari perawat dan sulit untuk berkonsentrasi saat menonton video musik baby shark yang diberikan kurang lebih selama 5 menit.

\begin{tabular}{|c|c|c|c|}
\hline $\begin{array}{l}\text { Pertemuan II } \\
\text { 19 Juli } 2019 \\
\text { Pukul } 19.00 \\
\text { WIB }\end{array}$ & $\begin{array}{l}\text { Melakukan intervensi } \\
\text { terapi musik baby } \\
\text { shark } \\
\text { menurunkan tingkat } \\
\text { kecemasan }\end{array}$ & $\begin{array}{l}\text { An. M tampak masih takut } \\
\text { saat perawat datang, wajah } \\
\text { masih cemberut, tetapi mulai } \\
\text { dapat mengikuti arahan dari } \\
\text { perawat untuk menonton } \\
\text { video musik baby shark yang } \\
\text { diberikan kurang lebih selama } \\
5 \text { menit. }\end{array}$ & $\begin{array}{l}\text { An. M tampak antusias } \\
\text { saat menonton video } \\
\text { bersama perawat dan } \\
\text { subjek penelitian tidak } \\
\text { ingin berhenti } \\
\text { menonton video yang } \\
\text { perawat berikan. }\end{array}$ \\
\hline $\begin{array}{l}\text { Pertemuan III } \\
\text { 20 Juli } 2019 \\
\text { Pukul } 19.00 \\
\text { WIB }\end{array}$ & $\begin{array}{l}\text { Melakukan intervensi } \\
\text { terapi musik baby } \\
\text { shark untuk } \\
\text { menurunkan tingkat } \\
\text { kecemasan dan } \\
\text { melakukan evaluasi } \\
\text { hasil intervensi }\end{array}$ & $\begin{array}{l}\text { An. M tampak lebih ceria dan } \\
\text { sudah mulai tersenyum kepada } \\
\text { perawat, sudah mengikuti } \\
\text { arahan dari perawat untuk } \\
\text { menonton video music baby } \\
\text { shark yang diberikan kurang } \\
\text { lebih selama } 5 \text { menit. }\end{array}$ & $\begin{array}{l}\text { An. M tampak } \\
\text { merespon apa yang di } \\
\text { bicarakan oleh perawat, } \\
\text { tampak ceria setelah } \\
\text { menonton video usik } \\
\text { baby shark kurang } \\
\text { lebih selama } 5 \text { menit. } \\
\text { Nafsu makan } \\
\text { meningkat, sudah tidak } \\
\text { ada mual. Skor } \\
\text { kecemasan yaitu 21, } \\
\text { yang merupakan tidak } \\
\text { ada kecemasan }\end{array}$ \\
\hline
\end{tabular}


Kondisi subjek penelitian I sebelum diberikan intervensi didapatkan hasil yang menunjukkan bahwa Subjek penelitian I tampak takut kepada perawat, menangis saat perawat datang, wajah tampak tegang dan sering cemberut, mata An.M tampak tajam saat menatap perawat, tingkat kecemasan sedang dengan skor 55, ibu dari subjek penelitian mengatakan An. M tidak nafsu makan, mual setiap habis makan,sering terbangun pada malam hari dan sulit tidur, demam sejak 3 hari yang lalu, sariawan dan kadang bibir berdarah.

Tabel. 2

Proses Intervensi Subjek Penelitian II

\begin{tabular}{|c|c|c|c|}
\hline Pertemuan & Tujuan & Respon & Kemajuan \\
\hline $\begin{array}{l}\text { Pertemuan I } \\
\text { 22 Juli } 2019 \\
\text { Pukul } \quad 09.30 \\
\text { WIB }\end{array}$ & $\begin{array}{lr}\text { Pengkajian, } & \text { Bina } \\
\text { Hubungan } & \text { Saling } \\
\text { Percaya } & \text { dan } \\
\text { penurunan } & \text { tingkat } \\
\text { kecemasan } & \end{array}$ & $\begin{array}{l}\text { An.F tampak gelisah, rewel, } \\
\text { takut saat melihat perawat } \\
\text { datang, wajah tampak tegang } \\
\text { dan cemberut, tidak ingin jauh } \\
\text { dari ibunya, tidak menjawab } \\
\text { ketika perawat tanya, sulit } \\
\text { berkonsentrasi. } \\
\text { kecemasan Skor } \\
\text { merupakan kecemasan sedang. } \\
\text { An.F mudah diajak untuk } \\
\text { mengikuti arahan dari perawat } \\
\text { untuk menonton video musik } \\
\text { baby shark yang diberikan } \\
\text { kurang lebih selama } 5 \text { menit } \\
\text { tetapi masih sulit untuk } \\
\text { berkonsentrasi pada saat } \\
\text { menonton video. }\end{array}$ & $\begin{array}{l}\text { An.F tertarik terhadap } \\
\text { ajakan perawat untuk } \\
\text { menonton video musik } \\
\text { baby shark yang akan } \\
\text { diberikan besok oleh } \\
\text { perawat }\end{array}$ \\
\hline $\begin{array}{l}\text { Pertemuan II } \\
\text { 23 Juli } 2019 \\
\text { Pukul } 19.00 \\
\text { WIB }\end{array}$ & $\begin{array}{l}\text { Melakukan intervensi } \\
\text { terapi musik baby } \\
\text { shark untuk } \\
\text { menurunkan tingkat } \\
\text { kecemasan }\end{array}$ & $\begin{array}{l}\text { An. F tampak malu saat } \\
\text { perawat ajak bicara. Saat } \\
\text { perawat mengajak bicara, } \\
\text { An.F hanya diam dan } \\
\text { tersenyum. An. F tidak ingin } \\
\text { jauh dari ibu nya saat mulai } \\
\text { menonton video musik baby } \\
\text { shark yang diberikan oleh } \\
\text { perawat, sulit berkonsentrasi } \\
\text { pada saat menonton video. }\end{array}$ & $\begin{array}{lr}\text { An.F tampak antusias } \\
\text { saat menonton video } \\
\text { musik baby shark, } \\
\text { sesekali } r \text { An.F } \\
\text { mengajak perawat } \\
\text { bicara dan bercanda. }\end{array}$ \\
\hline $\begin{array}{l}\text { Pertemuan III } \\
\text { 24 Juli } 2019 \\
\text { Pukul } 19.00 \\
\text { WIB }\end{array}$ & $\begin{array}{l}\text { Melakukan intervensi } \\
\text { terapi musik baby } \\
\text { shark untuk } \\
\text { menurunkan tingkat } \\
\text { kecemasan dan } \\
\text { melakukan evaluasi } \\
\text { hasil intervensi. }\end{array}$ & $\begin{array}{l}\text { An. F tampak ceria, dan } \\
\text { semangat saat ingin menonton } \\
\text { video musik baby shark yang } \\
\text { akan diberikan oleh perawat. } \\
\text { Skor kecemasan yaitu, } \\
\text { merupakan kecemasan ringan. }\end{array}$ & $\begin{array}{l}\text { An.F tampak senang } \\
\text { setelah menonton video } \\
\text { musik baby shark, } \\
\text { sudah tidak malu saat } \\
\text { diajak bicara oleh } \\
\text { perawat. An.F suka } \\
\text { mengajak perawat } \\
\text { bercanda. } \\
\text { kecemasan saat ini } \\
\text { yaitu 30, merupakan } \\
\text { kecemasan ringan. }\end{array}$ \\
\hline
\end{tabular}

Kondisi subjek penelitian II sebelum diberikan intervensi didapatkan hasil yang menunjukkan bahwa Subjek penelitian II tampak gelisah, rewel, takut dan menangis ketika perawat datang, wajah tampak tegang, gemetar, tidak bisa jauh dari ibunya, tingkat kecemasan sedang dengan skor 60, mata tampak tidak fokus, sulit diajak bicara 
dan berinteraksi oleh perawat, menangis ketika diberi obat injeksi, ibu dari subjek penelitian mengatakan An. F tidak nafsu makan dan sulit tidur, batuk.

Tabel. 3

Perbandingan Kondisi Klien Sebelum dan Sesudah Dilakukan Intervensi pada Subjek I

\begin{tabular}{|c|c|c|c|}
\hline $\begin{array}{l}\text { Hari } \\
\text { Ke- }\end{array}$ & Aspek & Sebelum & Sesudah \\
\hline \multirow{3}{*}{ I } & Respon fisiologis & $\begin{array}{l}\text { Gelisah, tidak nafsu makan } \\
\text { karena sariawan dan bibir } \\
\text { berdarah, sulit tidur, demam } \\
\text { dan mual. Nadi : } 130 x / \text { menit }\end{array}$ & $\begin{array}{l}\text { Cemas berkurang, tidak nafsu } \\
\text { makan, demam menurun. }\end{array}$ \\
\hline & Respon kognitif & $\begin{array}{l}\text { Sulit berkonsentrasi saat } \\
\text { diberikan terapi menonton } \\
\text { video musik baby shark. }\end{array}$ & $\begin{array}{l}\text { Kemampuan berkonsentrasi mulai } \\
\text { meningkat }\end{array}$ \\
\hline & $\begin{array}{l}\text { Respon perilaku dan } \\
\text { emosional }\end{array}$ & $\begin{array}{l}\text { Takut ketika perawat } \\
\text { datang,wajah cemberut, tidak } \\
\text { menatap perawat, dan tampak } \\
\text { diam. }\end{array}$ & $\begin{array}{l}\text { Masih sedikit takut, tidak mau } \\
\text { jauh dari orang tuanya, tetapi } \\
\text { sudah mulai tersenyum pada } \\
\text { perawat. }\end{array}$ \\
\hline \multirow{3}{*}{ II } & Respon fisiologis & $\begin{array}{l}\text { Cemas dan gelisah mulai } \\
\text { berkurang, tidur nyenyak, } \\
\text { nafsu makan mulai meningkat, } \\
\text { sudah tidak demam dan mual. } \\
\text { Nadi: } 112 \mathrm{x} / \text { menit }\end{array}$ & $\begin{array}{l}\text { Cemas sudah berkurang, tidak } \\
\text { gelisah, nafsu makan mulai } \\
\text { meningkat dan dapat tidur } \\
\text { nyenyak dimalam hari. }\end{array}$ \\
\hline & Respon kognitif & $\begin{array}{l}\text { Kemampuan berkonsentrasi } \\
\text { sudah mulai meningkat. }\end{array}$ & $\begin{array}{l}\text { Kemampuan berkonsentrasi sudah } \\
\text { meningkat dan mulai dapat } \\
\text { mengikuti arahan dari perawat }\end{array}$ \\
\hline & $\begin{array}{l}\text { Respon perilaku dan } \\
\text { emosional }\end{array}$ & $\begin{array}{l}\text { Wajah mulai rileks dan mulai } \\
\text { tersenyum kepada perawat } \\
\text { yang datang tetapi masih } \\
\text { sering diam dan malu } \\
\text { menjawab ketika ditanya oleh } \\
\text { perawat. }\end{array}$ & $\begin{array}{l}\text { An. M tampak ceria, tetapi kadang } \\
\text { masih malu ketika ditanya oleh } \\
\text { perawat. }\end{array}$ \\
\hline \multirow{3}{*}{ III } & Respon fisiologis & $\begin{array}{l}\text { cemas berkurang, tidak } \\
\text { gelisah, tidur nyenyak, nafsu } \\
\text { makan meningkat. Nadi : } \\
\text { 110x/menit }\end{array}$ & $\begin{array}{l}\text { An.M sudah tidak gelisah, nafsu } \\
\text { makan meningkat dan dapat tidur } \\
\text { nyenyak dimalam hari. }\end{array}$ \\
\hline & Respon kognitif & $\begin{array}{l}\text { Kemampuan berkonsentrasi } \\
\text { dalam menonton video musik } \\
\text { baby shark meningkat. }\end{array}$ & $\begin{array}{l}\text { Kemampuan berkonsentrasi } \\
\text { meningkat dan anak sudah tampak } \\
\text { ceria. }\end{array}$ \\
\hline & $\begin{array}{l}\text { Respon perilaku dan } \\
\text { emosional }\end{array}$ & $\begin{array}{l}\text { Wajah anak tampak rileks, } \\
\text { tersenyum terhadap perawat } \\
\text { yang datang dan sudah tidak } \\
\text { malu dan mau berinteraksi } \\
\text { dengan perawat. }\end{array}$ & $\begin{array}{l}\text { An.M tampak ceria dan sudah } \\
\text { mulai menjawab ketika ditanya } \\
\text { oleh perawat. }\end{array}$ \\
\hline
\end{tabular}

Kondisi subjek penelitian I setelah diberikan intervensi dari hasil evaluasi adalah terdapat penurunan tingkat kecemasan yang dialami oleh An. M dengan skor 21 yaitu tidak ada kecemasan. An.M tampak ceria dan mulai berinteraksi dengan perawat yang ada disekitarnya, kemampuan berkonsentrasi meningkat. Kondisi subjek penelitian II setelah diberikan intervensi dari hasil evaluasi adalah terdapat penurunan tingkat kecemasan yang dialami oleh An. F dengan skor 30 yaitu kecemasan ringan. An.F tampak ceria dan mulai berinteraksi dengan perawat yang ada disekitarnya, kemampuan berkonsentrasi meningkat. 
Tabel. 4

Perbandingan Kondisi Klien Sebelum dan Sesudah Dilakukan Intervensi pada Subjek II

\begin{tabular}{|c|c|c|c|}
\hline $\begin{array}{c}\text { Hari } \\
\mathrm{Ke}\end{array}$ & Aspek & Sebelum & Sesudah \\
\hline \multirow[t]{3}{*}{ I } & Respon fisiologis & $\begin{array}{l}\text { Gelisah, rewel, takut ketika } \\
\text { perawat datang, wajah tampak } \\
\text { tegang, gemetar, tidak bisa } \\
\text { jauh dari ibunya, sulit diajak } \\
\text { bicara dan berinteraksi oleh } \\
\text { perawat, anak tampak diam, } \\
\text { tidak nafsu makan, sulit tidur. } \\
\text { Nadi : } 128 \times \text { menit. }\end{array}$ & $\begin{array}{l}\text { Gelisah dan cemas berkurang, } \\
\text { sudah mulai mau berinteraksi } \\
\text { dengan perawat, tidak nafsu } \\
\text { makan dan sulit tidur. }\end{array}$ \\
\hline & Respon kognitif & $\begin{array}{l}\text { Sulit berkonsentrasi saat } \\
\text { diberikan terapi menonton } \\
\text { video musik baby shark. }\end{array}$ & $\begin{array}{l}\text { Kemampuan berkonsentrasi sudah } \\
\text { mulai meningkat. }\end{array}$ \\
\hline & $\begin{array}{l}\text { Respon perilaku dan } \\
\text { emosional }\end{array}$ & $\begin{array}{l}\text { Takut dan tampak diam ketika } \\
\text { perawat datang } \\
\text { menghampirinya. }\end{array}$ & $\begin{array}{l}\text { Rasa takut sudah mulai berkurang } \\
\text { tetapi anak tidak mau jauh dari } \\
\text { ibu nya. }\end{array}$ \\
\hline \multirow{3}{*}{ II } & Respon fisiologis & $\begin{array}{l}\text { Cemas sudah mulai } \\
\text { berkurang, tidur nyenyak, } \\
\text { nafsu makan sudah mulai } \\
\text { meningkat, anak sudah mau } \\
\text { berinteraksi dengan perawat. } \\
\text { Nadi: } 120 x / \text { menit }\end{array}$ & $\begin{array}{l}\text { Cemas sudah makin berkurang, } \\
\text { tidur nyenyak nafsu makan sudah } \\
\text { meningkat, dan anak sudah mulai } \\
\text { aktif. }\end{array}$ \\
\hline & Respon kognitif & $\begin{array}{l}\text { Kemampuan berkonsentrasi } \\
\text { meningkat saat diberikan } \\
\text { terapi menonton video musik } \\
\text { baby shark. }\end{array}$ & $\begin{array}{l}\text { Kemampuan } \\
\text { meningkat dan anak aktif } \\
\text { mengikuti nyanyian baby shark. }\end{array}$ \\
\hline & $\begin{array}{l}\text { Respon perilaku dan } \\
\text { emosional }\end{array}$ & $\begin{array}{l}\text { Wajah rileks dan tersenyum } \\
\text { kepada perawat yang datang. }\end{array}$ & $\begin{array}{l}\text { An.F tampak antusias, ceria dan } \\
\text { aktif. }\end{array}$ \\
\hline \multirow{3}{*}{ III } & Respon fisiologis & $\begin{array}{l}\text { Sedikit rewel, nafsu makan } \\
\text { meningkat dan tidur nyenyak } \\
\text { dimalam } \text { hari. } \\
118 x / \text { menit }\end{array}$ & $\begin{array}{l}\text { cemas dan gelisah berkurang, } \\
\text { nafsu makan meningkat dan tidur } \\
\text { nyenyak dimalam hari. }\end{array}$ \\
\hline & Respon kognitif & $\begin{array}{l}\text { Kemampuan berkonsentrasi } \\
\text { meningkat saat menonton } \\
\text { video musik baby shark dan } \\
\text { dapat mengikuti arahan } \\
\text { perawat. }\end{array}$ & $\begin{array}{l}\text { Kemampuan berkonsentrasi } \\
\text { meningkat dan anak sudah pintar } \\
\text { menyanyikan lagu baby shark. }\end{array}$ \\
\hline & $\begin{array}{l}\text { Respon prilaku dan } \\
\text { emosional }\end{array}$ & $\begin{array}{l}\text { Wajah tampak rileks, dan } \\
\text { tersenyum kepada perawat } \\
\text { yang datang. }\end{array}$ & An.F sangat ceria dan aktif. \\
\hline
\end{tabular}

Berdasarkan hasil penelitian yang dilakukan menunjukkan penurunan kecemasan pada kedua subjek penelitian yaitu dari kecemasan sedang pada awal pengkajian menjadi kecemasan ringan dan tidak ada kecemasan pada hari ketiga penelitian. Pada subjek I yaitu An.M dari skor 55 mengalami penurunan skor kecemasan menjadi 21, sedangkan pada subjek II yaitu An.F dari skor 60 mengalami penurunan skor kecemasan menjadi 30. 


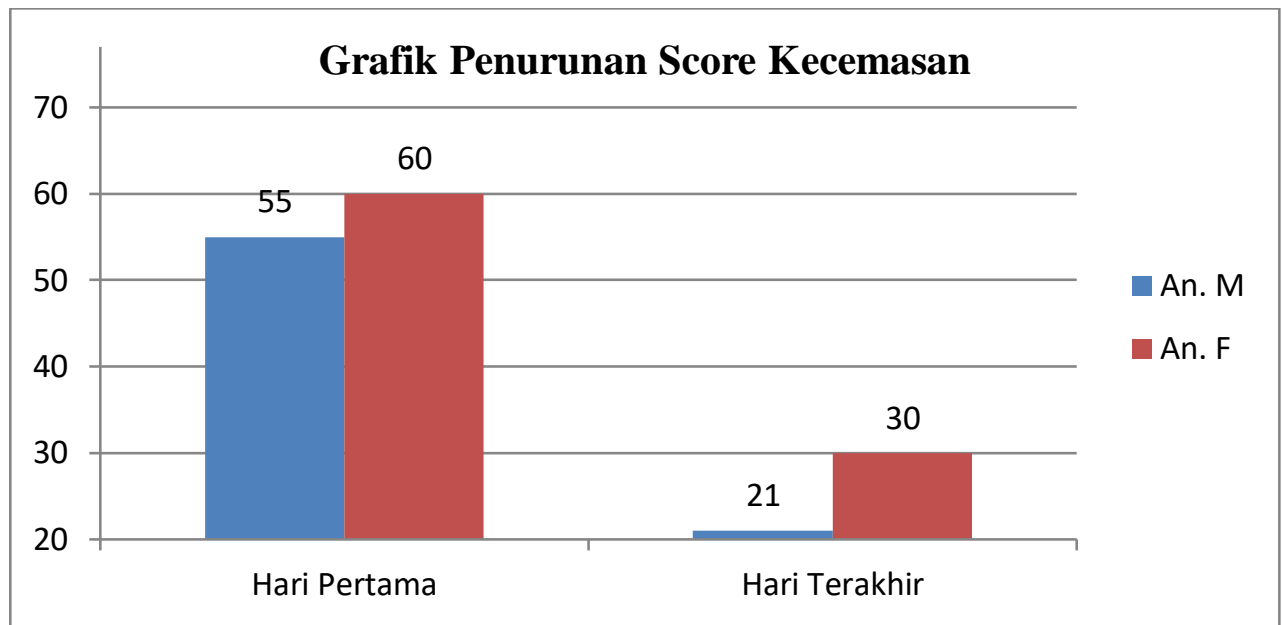

Grafik. 1

Penurunan Skor Kecemasan pada Subjek I dan Subjek II

Berdasarkan grafik diatas menunjukkan bahwa terjadi penurunan skor kecemasan pada An. M dan anak. F pada hari pertama dan hari terakhir diberikan intervensi.

\section{PEMBAHASAN}

Subjek penelitian I dan II telah mengalami penurunan pada tingkat kecemasan yang sama. Subjek penelitian I bernama An. M berumur 4 tahun 3 bulan, jenis kelamin laki-laki dan subjek penelitian II bernama An. F berumur 4 tahun berjenis kelamin perempuan. Penurunan tingkat kecemasan dari kecemasan sedang menjadi kecemasan ringan dan tidak ada kecemasan selama 3 hari berturut-turut dimana kedua subjek penelitian sama-sama diberikan intervensi terapi musik baby shark. Penurunan kecemasan disebabkan karena selama proses intervensi yang dilakukan pada subjek I dan subjek II menunjukan adanya perubahan fisiologis, perilaku emosional serta kemampuan kognitif.

Hal ini didukung oleh penelitian yang dilakukan oleh Yuliana \& Nela (2018) yang menyatakan bahwa adanya pengaruh intervensi terapi musik baby shark terhadap perubahan fisiologis seperti menurunnya frekuensi nadi, dan perubahan perilaku emosional serta kognitif pada anak yang menjalani hospitalisasi sehingga tingkat kecemasan dapat menurun.

Kedua subjek penelitian yang diberikan terapi musik baby shark saat dilakukan oleh peneliti, diperoleh hasil akhir memiliki jenis kelamin berbeda yaitu subjek penelitian I berjenis kelamin laki-laki dan subjek penelitian II berjenis kelamin perempuan, dimana kedua subjek penelitian memiliki penurunan tingkat kecemasan yang berbeda yaitu pada subjek penelitian I tidak ada kecemasan dengan skor kecemasan 21 dan kecemasan ringan dengan skor 30 pada subjek penelitian II, lebih tinggi dibandingkan dengan subjek penelitian I.

Penelitian Ulfa \& Kurniawati (2015) menunjukkan sesudah perlakuan responden pada kelompok perlakuan tigkat kecemasan mengalami penurunan. Sedangkan pada kelompok kontrol mayoritas tidak mengalam penurunan, meskipun ada yang mengalami penurunan yaitu 1 anak. Hal ini dikarenakan vibrasi musik yang mengalun melalui gendang telinga diterima oleh system saraf pusat melalui syaraf auditori lalu Hipotalamus mengeluarkan Hormon Ptuitari sehingga endorphin meningkat 
mengakibatkan rasa rileks, fly, nyeri menurun, senang, tenang sehingga mekanisme koping anak adaptif dan tingkat kecemasan turun.

Sejalan dengan penelitian Sari \& Suryani (2017) hasil penelitian ini menunjukkan tingkat kecemasan anak todler sebelum dilakukan intervensi terapi musik adalah sedang dan berat dengan nilai rata-rata 28,2. Tingkat kecemasan anak todler setelah dilakukan intervensi terapi musik lebih dari separuh adalah ringan dengan nilai rata-rata 18,80 . Tingkat kecemasan anak todler sebelum dan sesudah dilakukan intervensi terapi musik dengan nilai rata-rata 9,40. Terdapat pengaruh pemberian terapi musik terhadap tingkat kecemasan anak usia todler di Ruang Anak RSUD Dr. Achmad Mochtar Bukittinggi tahun 2016. Penelitian Permana (2017) menunjukkan bahwa terdapat pengaruh terapi musik (lagu anak-anak) terhadap kecemasan pada anak usia prasekolah akibat hospitalisasi di RS Amal Sehat Wonogiri.

Hal ini didukung oleh hasil penelitian yang dilakukan oleh Mia et al., (2017) menunjukkan bahwa responden anak yang mengalami kecemasan akibat hospitalisasi di Irina E RSUP Prof. Dr. R. D. Kandou Manado terbanyak yakni berjenis kelamin perempuan yang berjumlah 38 orang dari 44 orang dengan persentase $86,4 \%$ sedangkan yang berjenis kelamin laki-laki lebih sedikit yakni berjumlah 6 orang dengan persentase 13,6 \%, dikarenakan anak laki-laki cenderung lebih mempunyai mental yang kuat dan aktif sehingga lebih mudah untuk beradaptasi dengan lingkungan rumah sakit dan kecemasan akibat hospitalisasi lebih minimal dibandingkan dengan anak perempuan.

Lama perawatan pada subjek penelitian I dan subjek penelitian II memiliki perbedaan sebelum dilakukan intervensi. Pada subjek penelitian I yaitu An.M dengan lama perawatan 2 hari dan subjek penelitian II yaitu An.F dengan lama perawatan 1 hari. Pada subjek penelitian II An.F dengan lama perawatan 1 hari mengalami kecemasan sedang dengan skor kecemasan 60, lebih tinggi dibandingkan dengan subjek penelitian I yaitu An.M yang juga mengalami kecemasan sedang namun dengan skor 55. Anak yang dirawat dirumah sakit selama lebih dari tiga hari tingkat kecemasan akan lebih rendah dibandingkan dengan anak yang baru menjalani perawatan. Karena semakin lama anak dirawat maka tingkat kecemasan akan berkurang.

Perbedaan usia subjek penelitian yang diberikan terapi musik baby shark yaitu pada subjek penelitian I An.M berusia 4 tahun 3 bulan sedangkan pada subjek penelitian II yaitu An.F berusia 4 tahun. Menurut teori yang dikemukakan oleh Heri \& Fazrin (2017) semakin tua seseorang maka semakin baik dalam mengendalikan emosinya. Stress hospitalisasi yang dialami oleh anak dapat terjadi karena anak belum dapat beradaptasi dengan lingkungan baru yang belum dikenalnya seperti rumah sakit.

Hasil penelitian yang dilakukan oleh peneliti kepada kedua subjek penelitian yaitu pada An.M di hari pertama sebelum diberikan terapi musik baby shark diperoleh skor 55 yaitu kecemasan sedang tetapi setelah selama 3 hari diberikan terapi musik baby shark tingkat kecemasan nya menurun dengan skor 21 yaitu tidak ada kecemasan . Pada An.F di hari pertama sebelum diberikan terapi musik baby shark diperoleh skor 60 (kecemasan sedang) tetapi setelah selama 3 hari diberikan terapi musik baby shark tingkat kecemasannya menurun dengan diperoleh skor 30 yaitu kecemasan ringan.

Menurut hasil penelitian yang dilakukan oleh Agustina (2016) yang menyatakan bahwa musik baby shark merupakan musik yang digemari oleh anak-anak karena memiliki lirik yang unik. Menurut Natalina (2013) musik baby shark memiliki gerakan dan lirik lagu yang mudah dihafal oleh anak serta video musik yang menarik sehingga musik tersebut menjadi salah satu musik yang disukai oleh anak-anak. Dibuktikan dengan sebelum terapi musik baby shark diberikan, anak diukur terlebih dahulu tingkat 
kecemasan yang dialami anak dan anak kembali diukur tingkat kecemasannya setelah diberikan terapi musik baby shark dan didapatkan hasil bahwa adanya penurunan kecemasan pada anak usia prasekolah.

\section{SIMPULAN}

Dalam penelitian ini didapatkan kesimpulan bahwa terapi musik baby shark dapat menurunkan tingkat kecemasan pada anak usia prasekolah yang pada penelitian ini menggunakan 2 subjek penelitian yang sama-sama diberikan terapi musik baby shark. Penurunan tingkat kecemasan disebabkan karena selama proses intervensi yang dilakukan pada subjek I dan II menunjukan adanya perbedaan fisiologis, kognitif, perilaku dan emosional. Faktor usia, lingkungan juga dapat menjadi salah satu faktor yang dapat menurunkan tingkat kecamasan anak yang dirawat.

\section{SARAN}

Terapi musik baby shark dapat diterapkan dalam proses asuhan keperawatan di Rumah Sakit PELNI Jakarta. Rumah sakit perlu menyediakan fasilitas peralatan bermain yang cukup untuk anak-anak yang dirawat dirumah sakit agar dapat menurunkan tingkat kecemasan akibat hospitalisasi. Sebaiknya calon subjek penelitian lebih dari dua, yang dapat menjadikan permasalahan yang lebih kompleks serta datadata yang didapat lebih bervariasi dan beragam.

Kepada institusi pendidikan untuk peneliti selanjutnya, disarankan terapi musik baby shark bisa lebih dikembangkan lagi, tidak hanya untuk menurunkan tingkat kecemasan tetapi bisa diterapkan untuk mengatasi gangguan pola tidur pada anak usia prasekolah yang dirawat dirumah sakit.

\section{DAFTAR PUSTAKA}

Agustina, H. (2016). Pengaruh Distraksi Audiovisual terhadap Respons Penerimaan Injeksi Intravena melalui Saluran Infus pada Anak Prasekolah di Ruangan Anak RSD Kalisat Jember .Skripsi. Universitas Muhammadiyah Jember

Ariani, I., Nurhaeni, N., \& Waluyanti, F. T. (2015). Pengaruh Terapi Musik terhadap Respon Fisiologis dan Perilaku Kecemasan Anak selama Hospitalisasi. Jurnal Kesehatan Al-Irsyad (JKA), VIII(2), 52-63

Badan Penelitian dan Pengembangan Kesehatan. (2013). Penyajian Pokok-Pokok Hasil Riset Kesehatan Dasar 2013. Jakarta: Kementrian Kesehatan RI

Heri, S., \& Fazrin, I. (2017). Penurunan Tingkat Kecemasan Anak Akibat Hospitalisasi dengan Penerapan Terapi Bermain. Jurnal Konseling Indonesia, 3(1), 9-12

Hockenberry, M. J., \& Wilson, D. (2013). Wong's Essentials Of Pediatric Nursing. Edisi 9. St. Louis: Mosby

Kazemi S., Ghazimoghaddam K., Besharat S., \& Kashani L. (2012). Music and Anxiety in Hospitalized Children. Journal of Clinical and Diagnostic Research, 6(1), 9496

Legi, J. R., Sulaiman, S., \& Purwanti, N. H. (2019). Pengaruh Storytelling dan GuidedImagery terhadap Tingkat Perubahan Kecemasan Anak Usia Prasekolah yang Dilakukan Tindakan Invasif. Journal of Telenursing, 1(1), 145-156. DOI: https://doi.org/10.31539/joting.v1i1.496

Mia, A., Franly, O., \& Fedinan, W. (2017). Hubungan Dampak Hospitalisasi Anak dengan Tingkat Kecemasan Orang Tua. E-Journal Keperawatan, 5(1),1-8 
Natalina, D. (2013). Terapi Musik Bidang Keperawatan. Jakarta: Mitra Wacana Media

Oktiawati, A., Khodijah, K., Ikawati S., \& Rizky C. D. (2017). Teori dan Konsep Keperawatan Pediatrik. Jakarta: Trans Info Media

Padila, P., Agusramon, A., \& Yera, Y. (2019). Terapi Story Telling dan Menonton Animasi Kartun terhadap Ansietas. Journal of Telenursing (JOTING), 1(1), 51-66. https://doi.org/10.31539/joting.v1i1.514

Padila, P., Andari, F. N., \& Andri, J. (2019). Hasil Skrining Perkembangan Anak Usia Toddler antara DDST dengan SDIDTK. Jurnal Keperawatan Silampari, 3(1), 244256. https://doi.org/10.31539/jks.v3i1.809

Padila, P., Andari, F. N., Harsismanto, J., Andri, J. (2019). Tumbuh Kembang Anak Usia Toddler Berbasis Research. Lubuklinggau: Asra

Permana, B. (2017). Pengaruh Terapi Musik (Lagu Anak-Anak) terhadap Kecemasan pada Anak Usia Prasekolah Akibat Hospitalisasi di RS Amal Sehat Wonogiri. Universitas Muhammadiyah Semarang

Sarfika, R. (2015). Pengaruh Teknik Distraksi Menonton Kartun Animasi terhadap Skala Nyeri Anak Usia Prasekolah saat Pemasangan Infus di Instalasi Rawat Inap Anak RSUP dr.M. Djamil Padang. Jurnal Ners Jurnal Keperawatan, 11(1), 3240

Sari, Y. K., \& Suryani, A. (2017). Pengaruh Pemberian Terapi Musik Klasik terhadap Tingkat Kecemasan Anak Usia Toodler yang Mengalami Hospitalisasi di RSUD Dr. Achmad Mochtar Bukittinggi Tahun 2016. Jurnal Kesehatan Prima Nusantara, 8(2), 106-108

Ulfa, A. F., \& Kurniawati, K. (2015). Pengaruh Terapi Musik terhadap Penurunan Tingkat Kecemasan Anak Prasekolah yang Mengalami Hospitalisasi di Paviliun Seruni RSUD Jombang. Jurnal Ilmu Kesehatan, 3(2), 1-5

WHO. (2017). Early Child Development. https://www.tandfonline.com/loi/gecd20?open=187\&year=2017\&repitition=0\#vol 187_2017

Yuliana, Y., \& Nela, N. (2018). Pengaruh Terapi Musik Baby Shark terhadap Kecemasan Anak Usia Prasekolah akibat Rawat Inap di RSUD Deli Serdang Lubuk Pakam. Sumatera Utara: Repositori Institusi USU 